\title{
The Potential Correlation between Natural Disasters and Cuba's Agricultural Performance ${ }^{1}$
}

José Alvarez ${ }^{2}$

On October 28, 2000, U.S. President Bill Clinton signed the Trade Sanctions Reform and Export Enhancement Act (TSRA) which allowed U.S. firms to sell food and agricultural products to Cuba and other countries. However, the Cuban government did not purchase any of these products until December of 2001 following the devastating damage caused by Hurricane Michelle to important agricultural areas in November of that year.

Cuban purchases from U.S. firms amounted to $\$ 4.319$ million in 2001, \$138.635 million in 2002, and $\$ 256.9$ million in 2003. Cuba became the 35th most important food and agricultural export market for the United States in 2003, up from last (226th) in 2000. Actual purchases and pending contracts in the first-half of 2004 are at a pace to move Cuba into the top 20 most important markets of U.S. food and agricultural exports. Furthermore, because current U.S. legislation requires that all Cuban purchases from the United States must be conducted on a cash basis, the lack of credit risk associated with these sales makes Cuba one of the most attractive export markets for U.S. firms.
Anticipating changes in U.S.-Cuba trade relations, the Food and Resource Economics Department at UF/IFAS initiated a research initiative on Cuba in 1990, including a 1993 collaborative agreement with the University of Havana, which has lasted to this day. (Most of the resulting publications can be found at http://www.cubanag.ifas.ufl.edu). We reiterate that our role as investigators is to provide the best available information and analyses from which rational decisions can be made. The reports included in this series intend to address the increasing level of interest in the Cuban market for food and agricultural products among U.S. firms and to assist them in becoming more familiar with that market. The complete list of documents in this series can be found by conducting a topical search for "Cuba" at http://edis.ifas.ufl.edu, or under "Additional Information" at the end of this document.

\section{Introduction}

Almost since the beginning of the revolution in 1959, the Cuban leadership and some foreign scholars have blamed nature for many of the failures or inefficiencies of Cuba's agricultural sector. It is

1. This is EDIS document FE490, a publication of the Department of Food and Resource Economics, Florida Cooperative Extension Service, UF/IFAS,

University of Florida, Gainesville, FL. Published July 2004. Please visit the EDIS website at http://edis.ifas.ufl.edu.

A more detailed discussion of floods, droughts, and cold fronts, and related proxy data on them, is available in Alvarez (2003), and

http://lanic.utexas.edu/project/asce/pdfs/volume13/alvarez.pdf.

The author would like to thank Jorge Pérez-López for his valuable comments on an earlier draft.

2. José Alvarez, Professor, Department of Food and Resource Economics, Everglades Research and Education Center, Belle Glade, FL, Florida Cooperative Extension Service, UF/IFAS, University of Florida, Gainesville, FL. 
interesting to note that "extreme climatic conditions" also have been used to justify other agricultural failures such as the Sandinista experiment in Nicaragua (Utting, 1992). Many pages could easily be filled with quotes from Cuban officials, especially from President Castro, to illustrate that point. Here are some examples:

- "And what was that forced us to pay attention to the hydraulic problem?... It was the draught phenomenon, the tremendous drought that took place in the years 1961 and 1962." Fidel Castro (1990, p. 282).

- "Our farmers cannot continue at the mercy of hurricanes, of floods, of droughts. Our work cannot depend on whether or not it rains." Fidel Castro (1990, p. 284).

- "First, all of Cuban agriculture performed more poorly during 1985 and 1986. This was principally attributable to two factors: (1) there was an intensifying drought from 1983 through 1986; by 1986, rainfall was 35 percent below the historical average; and (2) in November 1985, Cuba experienced its most devastating hurricane since the revolution." Andrew Zimbalist and Claes Brundenius (1991, pp. 250, 258).

- "Due to the embargo, and to adverse climatic conditions, production of vegetables, and meat from cattle, pigs and fowl decreased [in 1999-2000].” Alfredo Jordán (Zúñiga, 2000, p. 1).

- "We have heavy damage from the drought to our sugarcane.... We have pushed back the [2000-20001] harvest start a bit to allow the cane to benefit a little more from the rain." Ulises Rosales del Toro ("Current Developments," 2000, p. 18).

- "We know that the imperialists sometimes have been trying to deflect hurricanes. And I suspect that, on certain occasions, to deflect them to where they are interested, even against us with counter-revolutionary purposes. We know-and it has been published - that the Pentagon was conducting experiments to see if they could make the clouds discharge their water without reaching Cuba." Fidel Castro (1990, p. 441).
These are just a sampling of the quotes on problems caused by droughts and hurricanes. The abundance of such quotes provided a challenge to research a series of questions: Can one really say that nature has been especially devastating during the current Cuban regime? Have there been more natural disasters during the socialist period than during similar prior periods? Is it easier to prepare for and recover from natural disasters after the revolution? If yes, why? Finally, and a sine qua non, could data on droughts, flooding from excessive rains, hurricanes, and cold fronts be found? With those questions in mind, the first step was to look for the definition of the events that encompass natural disasters that apply to Cuba.The next step was to search the literature to see what data were available. The objective was to compare the period 1959-2002 with 1915-1958 (i.e., 43 years before and after the revolution). Since data for cold fronts, flooding, and drought were not available or published in a useful format (see Alvarez, 2003), this fact sheet concentrates on the intensity and severity of hurricanes.

An important source was the website of the U.S. National Oceanographic and Atmospheric Administration. One of the documents related to hurricanes contains appropriate data to ascertain whether there are any differences between the two periods under study. A very comprehensive and voluminous publication by Rappaport and Fernandez-Partagas (n.d.) covers the period 1492 to 1997. Both were used in an attempt to elucidate the questions posed at the beginning of this fact sheet.

\section{The Incidence and Severity of Hurricanes in Cuba, 1915-1958 and 1959-2002}

Information on Atlantic tropical hurricanes (those in the North Atlantic Ocean, the Caribbean Sea, and the Gulf of Mexico) dating from 1492 to now have been compiled from historical documents and current weather data by Rappaport and Fernandez-Partagas. They list a total of 467 hurricanes. The first list contains the 259 deadliest hurricanes that caused at least 25 deaths. The second list contains 208 hurricanes that may have caused at least 25 deaths. Twelve of the hurricanes in the first list (the deadliest hurricanes) affected Cuba and none 
in the second list. Ten of the 12 hurricanes hit Cuba during the 1915-1958 period, but only two did so after 1959 (Table 1). That would give an incidence of one hurricane every 4.2 years for the first period versus one hurricane every 21.5 years for the second period. That, however, does not seem reasonable and is only part of the story.

More detailed data are provided in Table 2. The seven Cuban cities or areas most likely to be hit by a hurricane or having one passing within 60 miles, based on the 1915-2002 data, are the Isle of Youth, Cabo Corrientes in the province of Pinar del Río, Havana, Cienfuegos, Manzanillo, Baracoa, and Nuevitas, with frequencies ranging from 2.64 years to 6.28 years, respectively. Those frequencies, of course, are based on averages. Countries and regions within a country can experience wide deviations from the averages. Cuba is a case in point for the last several years. Hurricane George swept the eastern part of Cuba in September of 1998, and one year later, in October of 1999, Hurricane Irene hit the western-central provinces. Hurricane Michelle damaged $45 \%$ of the island in November of 2001, resulting in the most devastating hurricane to Cuba of the last 50 years. Then came Hurricanes Isidore and Lili, in October and November of 2002, respectively, which affected the Isle of Youth and the province of Pinar del Río within days of each other. These five hurricanes proved devastating to Cuban agriculture.

Table 2 also contains the number of times that each of the seven areas in Cuba has had a hurricane pass within 60 miles offshore and the number of times Cuba has experienced a direct hit. During the 1915-1958 period, these seven cities/areas experienced contact within 60 miles offshore more often (83 times) than during the 1959-2002 period (60 times). The opposite is the case with respect to the frequency of actual hits; there were 16 hits during the first period and 32 hits during the second period. It is very difficult to arrive at a definite conclusion.

To check for the statistical significance of these differences, a Student's t-test for both events was performed. This tool tests the means of two small samples to determine whether differences between them are significant. The results show that, concerning hurricanes brushing the island or passing within 60 miles offshore, the differences between the sample means of the two periods are statistically significant at $\mathrm{P}<0.07$. Therefore, the greater number of events during the first period is in fact significant. Concerning direct hits, the results show that the differences between the two periods are statistically significant at $\mathrm{P}<0.01$. It is safe to assume with $99 \%$ confidence that Cuba has been hit by hurricanes more times during the 1959-2002 period than during the 1915-1958 period. Therefore, it is appropriate to state that the data in Table 2 convey a statistical significance: there were more brushes of hurricanes within 60 miles offshore during the 1915-1958 period, but more direct hits during 1959-2002.

The frequency numbers, however, do not tell the whole story. For example, and since we are discussing the impact of natural disasters on agriculture, a hurricane classified as Category 2 (winds 96-110 miles per hour) may be worse for agriculture than one classified as Category 3 (winds 111-130 miles per hour). It depends on whether its path crossed important agricultural areas. Using the classification based on the number of deaths may also be misleading in terms of the impact on agriculture. First, the casualties may have occurred in the cities, with little damage to agriculture. Second, a certain number of deaths may not be recorded because precautionary measures were taken to minimize a hurricane's impact.

The latter may be particularly relevant for contemporary Cuba. Cuba has developed an impressive Civil Defense System (Defensa Civil) which was established by Law 1194 of 1966 and placed under the Ministry of the Armed Forces. During the process of institutionalization of the revolution in the mid-1970s, the Civil Defense System (CDS) was associated more closely with the Committees for the Defense of the Revolution (CDR), becoming an integral part of the system, as dictated by Law 1316 of the same year (Lezcano, 1995, p. 401). Cuba also has a good national meteorological service. When a hurricane is approaching, the CDS evacuates residents from the coastal and low areas, moving them to shelters until the storm has passed. This action changes the number of casualties. Looking only the relationship between the classification of the hurricane and the number of 
deaths is misleading because deaths can be prevented by timely evacuation.

\section{Summary and Conclusions}

A definite answer to the questions posed at the beginning of this paper cannot be provided. Lack of data hindered the analysis of cold fronts, flooding, and drought. In the case of the latter, there are abundant descriptions and quantifications on the more damaging droughts in the 1959-2001 period.

However, there is no consistent reporting and there is no data for the pre-1959 period.

This is not the case with hurricanes. Detailed data are available on the number of hurricanes affecting the archipelago, but not on the agricultural or economic damage they may have caused. The Economic Commission for Latin America and the Caribbean (ECLAC) has developed a disaster assessment methodology for the Caribbean region. It identifies the long-term social and economic effects of a natural disaster. With the caveats stated above, the numerical results show:

- Data on the 12 hurricanes causing at least 25 deaths from 1916-1997 show that 10 occurred during the 1915-1958 period and only two during the 1959-2002 period.

- Data on the number of times hurricanes have passed within 60 miles of the coast also show a significant difference between the two periods: 83 times during the 1915-1958 period and 60 during the 1959-2002 period. The analysis using a simple t-test confirms the statistical significance of that difference. The variable analyzed here, however, does not reflect the agricultural or economic damage those hurricanes might have caused to Cuba.

- Data on the number of times a hurricane hit the archipelago indicate 16 hurricanes during the 1915-1958 period and 32 hurricanes during the 1959-2002 period. The analysis using a simple t-test confirms the statistical significance of that difference. This variable appears to be a better indicator of agricultural and/or economic damage since the storms actually entered Cuba. The difference in the level of damage between the two periods, however, cannot be determined.

- Data on hurricane strength based on category level and/or wind velocity are also misleading because information on both agricultural and economic damage, and on the path of the storms during the two periods, is not available.

- Hurricane damage preparation and recovery information is incomplete for the 1959-2002 period and little information is available for the 1915-1958 period. This fact impeded the analysis of this important aspect of the impact of natural disasters. However, the existence of a very effective system of civil defense in socialist Cuba leads one to conclude that the process of damage prevention and recovery is better now than in the past.

To conclude, let us summarize the answers to the questions posed at the beginning of this fact sheet:

- Can we really say that nature has been especially devastating during the current Cuban regime? No, we cannot, but neither can we give an affirmative answer about the 1915-1958 period.

- Have there been more natural disasters during the socialist period than during a similar period prior to the revolution? In terms of hurricanes, the answer is "no" and "yes." The answer is "no" because the 1915-1958 period experienced more brushes/passing of hurricanes than the 1959-2002 period. However, the answer is "yes" for the frequency with which Cuba has been actually hit by hurricanes. Both answers convey high statistical significance.

- Has it been easier to prepare for and recover from those disasters after the revolution? If yes, why? It seems that the answer is "yes." The current civil defense system may be the reason. However, recovery from the loss of financial resources was not explored. Therefore, the answer would appear to be a qualified "yes." 


\section{References}

Alvarez, José. 2003. Natural Disasters and Cubas Agricultural Performance: Is There a Correlation? Cuba in Transition 13, Proceedings of the Thirteenth Annual Conference of the Association for the Study of the Cuban Economy, Coral Gables, FL, August, pp. 227-233. Also available at http://lanic.utexas.edu/project/asce/pdfs/volume13/ alvarez.pdf.

Castro, Fidel. Ciencia, Tecnología y Sociedad 1959-1989. 1990. La Habana: Editorial Política.

Current Developments in the Cuban Sugar Industry. 2000. Sugar y Azúcar 95 (11): 18-19, 22-23.

Lezcano, José Carlos. 1995. Aspectos Esenciales Sobre la Mitigación de los Desastres Naturales en Cuba. Cuba in Transition 5, Proceedings of the Fifth Annual Meeting of the Association for the Study of the Cuban Economy, Miami, FL, August, pp. 399-406.

Rappaport, Edward N. and Jose Fernandez Partagas. n.d. The Deadliest Atlantic Tropical Cyclones, 1492-Present. (http://www.nhc.noaa.gov).

Utting, Peter. 1992. Economic Reform and Third World Socialism - A Political Economy of Food Policy in Post-Revolutionary Societies. London: The Macmillan Press.

Zimbalist, Andrew and Claes Brundenius. 1991. The Organization and Performance of Cuban Agriculture. In Modernization and Stagnation-Latin American Agriculture Into the 1990s, edited by M.J. Twomey and A. Helwege, pp. 233-260. New York: Greenwood Press.

Zúñiga, Jesús. 2000. Cuban Minister of Agriculture Blames Embargo for Deficiencies. CubaNet.

\section{Additional Information}

Below is a list of the fact sheets in this series on Cuban Agriculture. They can be accessed by clicking on the highlighted links:
- FE479 - Cuban Agriculture Before 1959: The Political and Economic Situations

- FE480 - Cuban Agriculture Before 1959: The Social Situation

- FE481 - Transformations in Cuban Agriculture After 1959

- FE482 - Overview of Cuba's Food Rationing System

- FE483 - The Issue of Food Security in Cuba

- FE484 - Acopio: Cuba's State Procurement and Distribution Agency

- FE485 - Antecedents of the Cuban Agricultural Policies of the 1990s

- FE486 - Chronology of Cuban Reform Policies with Emphasis on Agriculture, 1993-1995

- FE487 - Cuba's Basic Units of Cooperative Production

- FE488 - Cuba's Agricultural Markets

- FE489 - Environmental Deterioration and Conservation in Cuban Agriculture

- FE490 - The Potential Correlation between Natural Disasters and Cuba's Agricultural Performance 
Table 1. Ranking of Atlantic tropical hurricanes causing at least 25 deaths in Cuba, 1915-1997. ${ }^{\text {a }}$

\begin{tabular}{|c|c|c|}
\hline $\begin{array}{c}\text { Rank } \\
\text { (by number of deaths) }\end{array}$ & Name of Hurricane $^{b}$ & Dates Active \\
\hline 5 & Flora & $\begin{array}{c}1963 \\
\text { September } 30-\text { October } 8\end{array}$ \\
\hline 10 & & $\begin{array}{c}1932 \\
\text { November } 4-\text { November } 10\end{array}$ \\
\hline 43 & & $\begin{array}{c}1926 \\
\text { October } 20\end{array}$ \\
\hline 50 & & $\begin{array}{c}1919 \\
\text { September } 9-\text { September } 14\end{array}$ \\
\hline 54 & Fox & $\begin{array}{c}1952 \\
\text { October 23 - October } 25\end{array}$ \\
\hline 78 & & $\begin{array}{c}1944 \\
\text { October } 12 \text { - October } 18\end{array}$ \\
\hline 79 & Hilda & $\begin{array}{c}1955 \\
\text { September } 11-\text { September } 16\end{array}$ \\
\hline 115 & & $\begin{array}{c}1933 \\
\text { August } 30-\text { September } 5\end{array}$ \\
\hline 155 & Alma & $\begin{array}{c}1966 \\
\text { June } 4-\text { June } 8\end{array}$ \\
\hline 165 & & $\begin{array}{c}1917 \\
\text { September 22 - September } 29\end{array}$ \\
\hline 168 & & $\begin{array}{c}1935 \\
\text { September } 23-\text { September } 29\end{array}$ \\
\hline 253 & & $\begin{array}{c}1950 \\
\text { August } 25-\text { August } 31\end{array}$ \\
\hline $\begin{array}{l}\text { a } \text { Atlantic refers to the Nort } \\
\text { b } \text { Hurricanes did not start } r \\
\text { Source: http://www.nhc.noa }\end{array}$ & $\begin{array}{l}\text { ean, the Caribbean Se } \\
\text { es until after } 1950 . \\
\text { adlya1.html }\end{array}$ & of Mexico. \\
\hline
\end{tabular}


Table 2. Frequency of Cuban areas/cities affected by hurricanes, 1915-1958 and 1959-2002.

\begin{tabular}{|c|c|c|c|c|c|}
\hline \multirow[t]{2}{*}{ Area or City } & \multirow{2}{*}{$\begin{array}{l}\text { How Often Area Is } \\
\text { Affected }^{\mathrm{a}} \\
(\text { years })\end{array}$} & \multicolumn{2}{|c|}{ Frequency Within 60 Miles } & \multicolumn{2}{|c|}{ Frequency of Area Hit } \\
\hline & & $1915-1958$ & $1959-2002$ & $1915-1958$ & $1959-2002$ \\
\hline Isle of Youth & 2.64 & 19 & 10 & 4 & 7 \\
\hline $\begin{array}{l}\text { Cabo Corrientes, } \\
\text { Pinar del Rio }\end{array}$ & 2.93 & 8 & 14 & 3 & 5 \\
\hline Havana & 3.14 & 13 & 13 & 5 & 10 \\
\hline Cienfuegos & 4.26 & 12 & 6 & 2 & 2 \\
\hline Manzanillo & 4.55 & 12 & 5 & 1 & 1 \\
\hline Baracoa & 4.71 & 10 & 8 & 0 & 4 \\
\hline Nuevitas & 6.28 & 9 & 4 & 1 & 3 \\
\hline Total & & 83 & 60 & 16 & 32 \\
\hline \multicolumn{6}{|c|}{$\begin{array}{l}\text { For comparison's sake: } \\
\text { - Grand Cayman ranks } 1 \text { (every } 2.24 \text { years) } \\
\text { - Morehead City, NC ranks } 51 \text { (every } 3.38 \text { years) } \\
\text { - Miami, FL ranks } 16 \text { (every } 2.75 \text { years). }\end{array}$} \\
\hline
\end{tabular}

